\title{
Assessment of groundwater quality with special emphasis on nitrate contamination in parts of Varanasi City, Uttar Pradesh, India
}

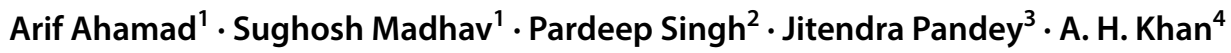

Received: 16 May 2017 / Accepted: 24 June 2018 / Published online: 5 July 2018

(c) The Author(s) 2018

\begin{abstract}
In the current study, an effort was made to assess the geochemistry of groundwater by random collection of the samples from 15 different borewells located in various parts of Varanasi City, Uttar Pradesh, India. Geology of the study region is dominated by Quaternary alluvial sediments of Pleistocene to recent times where the younger alluvium receives fresh deposits of silt, clay and loam from periodic flood events. $\mathrm{Ca}-\mathrm{Mg}-\mathrm{HCO}_{3}$ was inferred as major hydrogeochemical facies from Piper trilinear diagram. Ca-Mg type and $\mathrm{HCO}_{3}{ }^{-}$type were the dominating cation and anion facies, respectively. Hydrogeochemistry reveals that the cation abundance follows the order $\mathrm{Na}^{+}>\mathrm{Mg}^{2+}>\mathrm{Ca}^{2+}>\mathrm{K}^{+}$and anion abundance $\mathrm{HCO}_{3}{ }^{-}>\mathrm{Cl}^{-}>\mathrm{NO}_{3}{ }^{-}>\mathrm{SO}_{4}{ }^{2-}>\mathrm{F}^{-}$. As per Gibb's plot, chemical weathering of rock minerals is affecting the quality of groundwater. Overall, most of the samples for majority of parameters lie within the allowable limits as set by WHO (guideline for drinking water quality, fourth edn, WHO, Geneva, p 340, 2004) except nitrate, which varied in the range of $40.32-78.97 \mathrm{mg} / \mathrm{l} .80 \%$ of the groundwater samples in which nitrate exceeded beyond acceptable limit $(50 \mathrm{mg} / \mathrm{l})$, as per WHO standard, which may be due to poor sewerage, human excreta leakage from septic tanks, poorly maintained disposal of solid waste locally, agricultural activities, wastewater irrigation and irrigation runoff. The Water quality index (WQI) value of the study region depicts that $93 \%$ samples lie in the category of excellent water and 7\% in good water category. Good positive correlation of $\mathrm{NO}_{3}-\mathrm{Cl}(r=0.60)$ and $\mathrm{Na}_{-} \mathrm{NO}_{3}$ $(r=0.55)$ signifies an anthropogenic input of these ions into the subsurface water of the study region. The various indices such as electrical conductivity (EC), salinity, percent sodium, sodium absorption ratio (SAR), residual sodium carbonate (RSC), permeability index (PI), Kelly's ratio and magnesium ratio are used to check the fitness of ground water for irrigation uses which shows that groundwater samples of the study region is good to permissible for agricultural uses.
\end{abstract}

Keywords Groundwater $\cdot$ TDS $\cdot$ Nitrate $\cdot$ Water quality index $\cdot$ Residual sodium carbonate (RSC)

\section{Introduction}

The most concerning issues to water authorities are to provide safe and potable drinking water to every individual for their good health (Jamshidzadeh and Barzi 2018). Due to deterioration of surface water quality and its shrinkage,

Arif Ahamad

evsarif786@gmail.com

1 School of Environmental Sciences, JNU, New Delhi 110067, India

2 PGDAV College, University of Delhi, New Delhi 110067 , India

3 Environmental Science Division, Centre of Advanced Study in Botany, Banaras Hindu University, Varanasi 221005, India

4 Environment Monitoring Division, CSIR-IITR, MG Road, Lucknow 226001, India and also due to the perception that the water below ground is pure, the most of the population in different countries use groundwater in daily routine (Raju et al. 2011; Madhav et al. 2018). Groundwater is considered as a primary water supply source in urban and rural regions of developing countries and its degradation is related to different types of health issues (Singh et al. 2016). Today, overexploitation of groundwater for various purposes (i.e., drinking and household, industrial and agricultural uses), as well as the seepage of sewages from diverse sources into the aquifers, has made significant variations in the groundwater quality (Annapoorna and Janardhana 2015; Ehya and Mosleh 2018; Mahmoudi et al. 2017; Alexander et al. 2017). The groundwater geochemistry is complex due to diverse reasons. Various factors such as percolation of surfaceand rainwater, complex hydrogeology, human influence on flow systems and contamination sources determine the 
chemical content (Amalraj and Pius 2018). The residence time of water and the primary mineralogy control the rate of reaction with parent rocks. Knowledge of groundwater quality is significant because it is an important aspect which determines its fitness for different purposes. The quality of water tells about environment, though the water circulated in the aquifer. We can never find water in its purest form; for the human metabolism, most of the elements are required in small amounts but if present in unwanted level, they show damaging effect and it turns into a disease inducing commodity. As a consequence of a geochemical change of rainwater recharging system, every groundwater system acquired a unique chemistry (Raju et al. 2015). The water quality index (WQI) is a productive tool to estimate the quality of water by integrating a composite set of data and generating a score which signify the overall water quality category (Jamshidzadeh and Barzi 2018). WQI could be an easy communication tool about the groundwater quality for local residents and government agencies in terms of better management in near future. The agrarian belt of Varanasi basically uses groundwater for irrigation purpose which is directly linked with crop yield. The groundwater is being drawn way faster than it is recharged. Thus, it is necessary step to examine the groundwater geochemistry and its irrigation suitability $(\mathrm{Li}$ et al. 2013).

The effects of irrigation, excess use of fertilizer and domestic sewage could enhance the ionic composition such as $\mathrm{NO}_{3}^{-}, \mathrm{Cl}^{-}, \mathrm{Na}^{+}$and $\mathrm{K}^{+}$in groundwater. Once contaminants go into the ground below, it may remain hidden for years, depicting groundwater unfit for human intake and other purposes (Raju 2012). In several parts of the world, groundwater $\mathrm{NO}_{3}{ }^{-}$contamination is a challenging task from different reasons like septic tank systems, manure or agricultural organic by-products, landfill sites that are unlined, punctured sewerage lines, poultry waste and domestic/farm animal manure (Suthar et al. 2009; Raju et al. 2009; Abdesselam et al. 2013; Ako et al. 2014). Unwarranted $\mathrm{NO}_{3}{ }^{-}$intake in drinking water has been linked with the risk of methemoglobinemia or 'blue baby syndrome' in humans, stomach cancer and nitrate poisoning in animals (Mason 2002; Raju et al. 2009; Stadler et al. 2012). Several researchers have studied on hydrogeochemistry, groundwater contamination and its suitability for domestic and irrigation purposes in different basins, urban and rural areas (Gowd 2005; Umar et al. 2009; Singh et al. 2011; Prasanth et al. 2012; Alaya et al. 2014; Raju et al. 2014, 2016; Patel et al. 2016; Ahamed and Loganathan 2017). Hence, the endeavor of the current study is to assess the hydrogeochemistry and fitness of groundwater for domestic and irrigation purposes of the study area based on different indices, i.e., WQI, salinity, percent sodium, sodium absorption ratio (SAR), residual sodium carbonate (RSC), permeability index (PI), Kelly's ratio and magnesium ratio.

\section{Study area and hydrogeology}

The middle Ganga plain makes the surrounding of the Varanasi area with flat topography. The maximum temperature is recorded to be $48{ }^{\circ} \mathrm{C}$ in the summer and $8{ }^{\circ} \mathrm{C}$ in winter. In the study area, average annual precipitation is about $1020 \mathrm{~mm}$. The study region lies between latitude $25^{\circ} 15^{\prime} 50^{\prime \prime} \mathrm{N}-25^{\circ} 19^{\prime} 50^{\prime \prime} \mathrm{N}$ and longitude $82^{\circ} 56^{\prime} 7^{\prime \prime} \mathrm{E}-83^{\circ} 00^{\prime} 42^{\prime \prime} \mathrm{E}$ (Fig. 1). Geology is dominated by Quaternary alluvial sediments of Pleistocene to recent times. The younger alluvium around the drainage courses receives fresh deposits of silt, clay and loam due to periodical flood events. In the Varanasi areas, a multilayer aquifer system is found which consists of alternating sand and clay layers (Shukla and Raju 2008). Holocene sandy units consist of shallow as well as semi-confined to confined deeper aquifers. The shallow borewells are $20-60 \mathrm{~m}$ in depth with water-level fluctuation of 9-12 $\mathrm{m}$ while deep tube wells depth ranges 60-250 m.

\section{Methodology}

\section{Sample collection}

A total of 15 subsurface water samples were taken from borewells in the study region during the month of April 2012. Selected borewells were constantly in use for daily need, i.e., drinking and domestic purposes. For validation and cross-check of result, a field duplicate sample was collected at every fifth sampling location. Samples were collected in polypropylene bottle rinsed with the same groundwater before filling. In order to stabilize the electrical conductivity (EC) and eradicate the standing water interference inside the metal casing, groundwater samples were collected after flushing water for 5-10 min. Groundwater samples were kept at $4{ }^{\circ} \mathrm{C}$ to avoid any chemical modification.

\section{Laboratory and data analysis}

All the analysis was done according to standard protocol (APHA 2005). pH, electrical conductivity (EC) and total dissolved solids (TDS) were measured in the field by using $\mathrm{pH}$ and conductivity meter. To filter samples, $0.45 \mu \mathrm{m}$ Millipore filter paper in vacuum filtration unit was used before the analysis of major cations and anions. The samples were then tested for major cations $\left(\mathrm{Ca}^{2+}, \mathrm{Mg}^{2+}, \mathrm{Na}^{+}\right.$and $\left.\mathrm{K}^{+}\right)$, anions $\left(\mathrm{HCO}_{3}{ }^{-}\right.$, $\mathrm{CO}_{3}{ }^{2-}, \mathrm{Cl}^{-}, \mathrm{SO}_{4}{ }^{2-}, \mathrm{NO}_{3}{ }^{-}$and $\mathrm{F}^{-}$), hardness and alkalinity. $\mathrm{Ca}^{2+}, \mathrm{Mg}^{2+}$ and hardness contents were measured by EDTA 
Fig. 1 Physiographic and sampling locations map of the study area (1-Maldahiya, 2-Rathyatra, 3-Chawk, 4-Bhagwanpur, 5-Naria, 6-Sigra, 7-Samane ghat, 8-Chandpur, 9-Mahmoorganj, 10-Lohta, 11-DLW, 12-Dalmandi, 13-Sundarpur, 14-Godauliya, 15-Beniyabagh)

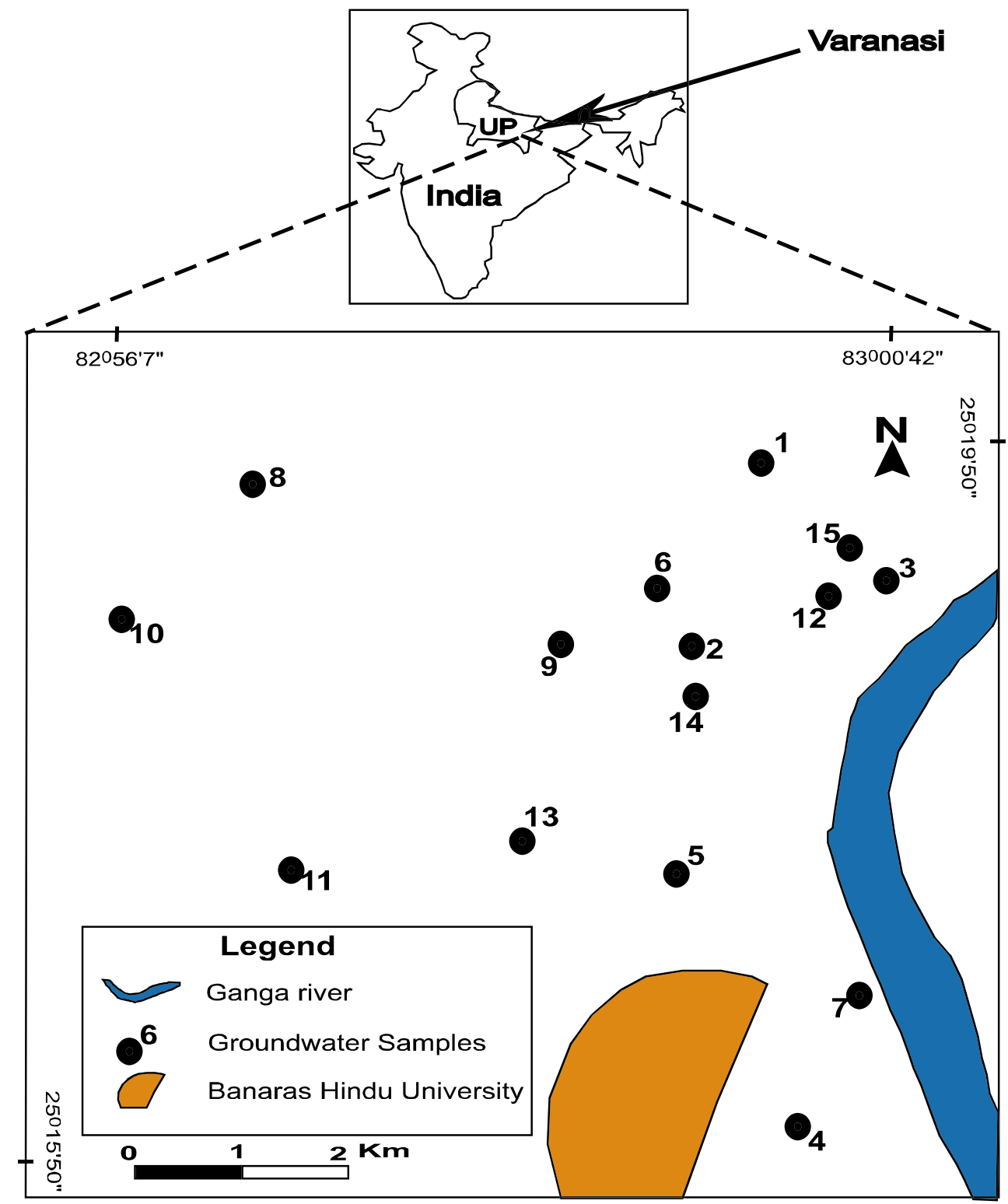

titrimetric method while $\mathrm{Na}^{+}$and $\mathrm{K}^{+}$contents were measured by Elico flame photometer. $\mathrm{Cl}^{-}$was calculated by $\mathrm{AgNO}_{3}$ titration. $\mathrm{HCO}_{3}{ }^{-}$concentration and alkalinity were calculated by electrometric titration method. $\mathrm{F}^{-}$content was measured during Orion ion selective electrode $4 \mathrm{Star} . \mathrm{NO}_{3}{ }^{-}$and $\mathrm{SO}_{4}{ }^{2-}$ contents were examined using UV-visible spectrophotometer. The accurate measurements of major cations and anions were examined by calculating electrical neutrality (EN \%) (Appelo and Postma 1993). EN \% values for all the samples were found within $\pm 5 \%$. Basic statistical parameters, inter-ionic relation graphs, US salinity Laboratory (1954) diagram, Wilcox (1948) diagram and permeability index plot (1964) were prepared by using Microsoft Excel Version 2007. AqQa software was used to prepare piper trilinear diagramme. Location map was prepared on Adobe Illustrator 10. Interpolation map was prepared by Arc GIS 9.3 software.
Water quality index (WQI) may understand as a rating scale that echoes the combined impact of diverse parameters of groundwater quality (Sahu and Sikdar 2008). Every parameters are accredited different weights (wi) in a scale of least effect (1) to highest effect (5) based on their apparent health impact and their significant magnitude in the drinking water quality (Sener et al. 2017) (Table 1). The highest weightage five is given to the parameters having severe health hazard (Varol and Davraz 2014). The assigned weight and relative weight of physiochemical criteria are given in Table 1 . The relative weight $\left(W_{i}\right)$ has been computed using the equation:

$W_{i}=\frac{w i}{\sum_{i=1}^{n} w i}$, 
Table 1 Chemical parameters and their relative weight

\begin{tabular}{llll}
\hline Parameters & $\begin{array}{l}\text { WHO stand- } \\
\text { ard (mg/l) }\end{array}$ & Weight (wi) & Relative weight (Wi) \\
\hline $\mathrm{pH}$ & 9.2 & 3 & 0.039 \\
$\mathrm{TH}$ & 500 & 2 & 0.026 \\
$\mathrm{TDS}$ & 1500 & 5 & 0.064 \\
$\mathrm{Ca}^{2+}$ & 200 & 2 & 0.026 \\
$\mathrm{Mg}^{2+}$ & 150 & 2 & 0.026 \\
$\mathrm{Na}^{+}$ & 200 & 2 & 0.026 \\
$\mathrm{~K}^{+}$ & 12 & 2 & 0.026 \\
$\mathrm{HCO}_{3}^{-}$ & 600 & 2 & 0.026 \\
$\mathrm{SO}_{4}^{2-}$ & 600 & 4 & 0.052 \\
$\mathrm{Cl}^{-}$ & 600 & 3 & 0.039 \\
$\mathrm{NO}_{3}^{-}$ & 50 & 5 & 0.064 \\
$\mathrm{~F}^{-}$ & 1.5 & 5 & 0.064 \\
& & $\sum \mathrm{wi}=37$ & $\sum \mathrm{Wi}=0.48$ \\
\hline
\end{tabular}

where $W_{i}$ is relative weight, wi is weight of each parameter and $n$ is the number of parameters. Then, the concentration of each parameter in each water sample is divided by its limit values given by the WHO and the output value is multiplied by 100 to get the quality rating (qi) for every parameter

$q_{i}=\left(C_{i} / S_{i}\right) \times 100$,

where $q_{i}$ represents the quality rating, $C_{i}$ the concentration of every physiochemical parameter in each water sample $(\mathrm{mg} / \mathrm{l})$ and $S_{i}$ the standard of drinking water $(\mathrm{mg} / \mathrm{l})$ for every chemical parameter as proposed by WHO. To calculate WQI, firstly $\mathrm{SI}_{i}$ value should be determined by the following equations, where

$\mathrm{SI}_{i}=W_{i} \times q_{i}$,

$\mathrm{WQI}=\sum \mathrm{SI}_{i}$,

$\mathrm{SI}_{\mathrm{i}}$ is the subindex of $i$ th parameter; $q_{i}$ is the quality rating based on the amount of $i$ th parameter.

Irrigation suitability is calculated with various indices; all values are in epm:

The RSC is calculated when the amount of alkaline earths is subtracted from the amount of carbonates:

$\mathrm{RSC}=\left(\mathrm{HCO}_{3}^{-}+\mathrm{CO}_{3}^{-}\right)-\left(\mathrm{Ca}^{+2}+\mathrm{Mg}^{+2}\right)$

The formula for calculating $\mathrm{Na} \%$ is:

$\mathrm{Na} \%=(\mathrm{Na}+\mathrm{K} / \mathrm{Ca}+\mathrm{Mg}+\mathrm{K}+\mathrm{Na}) \times 100$

The extent of $\mathrm{Na}^{+}$present in the water can be estimated by SAR which is expressed as follows:

$\mathrm{SAR}=\mathrm{Na}^{+} / \sqrt{ } \mathrm{Ca}^{+2}+\mathrm{Mg}^{+2} / 2$
Permeability Index $(\mathrm{PI})=\mathrm{Na}^{+}$

$$
+\sqrt{ } \mathrm{HCO}_{3}^{-} /\left(\mathrm{Ca}^{2+}+\mathrm{Mg}^{2+}+\mathrm{Na}^{+}\right) \times 100
$$

Kelly's ratio $=\mathrm{Na}^{+} / \mathrm{Ca}^{2+}+\mathrm{Mg}^{2+}$

Magnesium Hazard $(\mathrm{MH})=\mathrm{Mg}^{2+} /\left(\mathrm{Ca}^{2+}+\mathrm{Mg}^{2+}\right) \times 100$

\section{Results and discussion}

\section{Major cation and anion chemistry}

The drinking water samples were devoid of color, odor and turbidity. The standard ranges for drinking water, as per WHO standards, were considered to determine its fitness for drinking purposes. The statistical summary of different physicochemical parameters is shown in Table 2. It showed that most of the samples for majority of parameters lie under the acceptable limit as set by WHO standard (2004) except nitrate. The $\mathrm{pH}$ ranges are 7.2-8.1 (mean 7.77). The groundwater samples are mainly alkaline of the study area. EC ( $\mu \mathrm{S} /$ $\mathrm{cm}$ ) varies 430-1110 (mean 759.33), which is an indication of the ionic concentrations. EC values display the safe zone for potability. The values of TDS (mg/l) range 240-800 (mean 490.67). Since the groundwater of the recent study lies under freshwater class and the TDS values for all samples are below $1000 \mathrm{mg} / \mathrm{l}$, it may be used for drinking and irrigation purposes (Davis and De Weist 1966).

Water hardness is originated mainly due to the polyvalent ions (primarily $\mathrm{Ca}^{2+}$ and $\mathrm{Mg}^{2+}$ ) ranging 216-480

Table 2 Statistical summary of physicochemical parameters and its comparison with WHO standards for groundwater samples

\begin{tabular}{lcrll}
\hline Parameters & \multicolumn{1}{l}{ Range } & Mean & WHO (2004) & $\begin{array}{l}\text { \% Sample } \\
\text { exceeding }\end{array}$ \\
\hline $\mathrm{pH}$ & $7.2-8.1$ & 7.77 & 8.5 & - \\
$\mathrm{EC}$ & $430-1110$ & 759.33 & & - \\
$\mathrm{TDS}$ & $240-800$ & 490.67 & 1500 & - \\
$\mathrm{Ca}^{2+}$ & $14-78$ & 45.60 & 200 & - \\
$\mathrm{Mg}^{2+}$ & $16.82-91.16$ & 56.23 & 150 & - \\
$\mathrm{Na}^{+}$ & $18.6-100.1$ & 57.92 & 200 & - \\
$\mathrm{K}^{+}$ & $0.6-119.5$ & 11.15 & 12 & 6 \\
$\mathrm{HCO}_{3}{ }^{-}$ & $190-610$ & 373.60 & 600 & 6 \\
$\mathrm{SO}_{4}{ }^{2-}$ & $3.39-182.1$ & 42.02 & 600 & - \\
$\mathrm{Cl}^{-}$ & $32-122$ & 66.80 & 600 & - \\
$\mathrm{NO}_{3}{ }^{-}$ & $40.32-78.97$ & 58.28 & 50 & 80 \\
$\mathrm{~F}^{-}$ & $0.13-1.9$ & 0.62 & 1.5 & 6 \\
$\mathrm{Hardness}^{-}$ & $216-480$ & 344.93 & 500 & - \\
$\mathrm{Alkalinity}^{-}$ & $155.8-500.2$ & 307.01 & & - \\
\hline
\end{tabular}


(mean 344.93). Among cationic composition (mg/l), $\mathrm{Na}^{+}$is leading ion ranging 18.6-100.1 (mean 57.92) followed by $\mathrm{Mg}^{2+}$ ranging $16.82-91.16$ (mean 56.23); $\mathrm{Ca}^{2+}$ ranging 14-78 (mean 45.6) and $\mathrm{K}^{+}$ranging 0.6-119.5 (mean 11.15). Among the anionic composition $(\mathrm{mg} / \mathrm{l})$, $\mathrm{HCO}_{3}{ }^{-}$is the leading ion ranging 190-610 (mean 373.60) afterward $\mathrm{Cl}^{-}$ranging 32-122 (mean 66.80); $\mathrm{NO}_{3}{ }^{-}$ranging 40.32-78.97 (mean 58.28); $\mathrm{SO}_{4}{ }^{2-}$ ranging 3.39-182.1 (mean 42.02); and $\mathrm{F}^{-}$ranging 0.13-1.9 (mean 0.62). So, hydrogeochemistry divulges that the cation abundance follows the order $\mathrm{Na}^{+}>\mathrm{Mg}^{2+}>\mathrm{Ca}^{2+}>\mathrm{K}^{+}$and anion abundance $\mathrm{HCO}_{3}{ }^{-}>\mathrm{Cl}^{-}>\mathrm{NO}_{3}{ }^{-}>\mathrm{SO}_{4}{ }^{2-}>\mathrm{F}^{-}$. Overall, it is found that rock weathering, dissolution and base exchange are the processes leading concentration of ions in the groundwater.

\section{Sources of ions in groundwater}

Diverse sources of ions and their interrelationship can be interpreted from correlation matrix (Table 3). Land usage patterns and pollution are primarily accountable for the variations in EC or TDS (Gillardet et al. 1999). Excess of agricultural manure input and its runoff, municipal and industrial sewage wastes and animal excreta essentially serve as major sources of $\mathrm{NO}_{3}{ }^{-}, \mathrm{Na}^{+}$and $\mathrm{Cl}^{-}$in the groundwater (Jalali 2009). These can further be co-related to EC variability in the groundwater, and the effect of anthropogenic actions on the water hydrochemistry can be understood (Han and Liu 2004). The relationship between different ions $\left(\mathrm{Na}^{+}, \mathrm{Cl}^{-}\right.$and $\mathrm{NO}_{3}{ }^{-}$) and EC is shown in (Table 3). Strong and substantial positive correlation between EC and $\mathrm{Mg}(r=0.71), \mathrm{Na}$ $(r=0.84), \mathrm{K}(r=0.48), \mathrm{HCO}_{3}(r=0.53), \mathrm{Cl}(r=0.78)$ and $\mathrm{NO}_{3}(r=0.59)$ is suggestive of significant anthropogenic activities leading to the addition of these ions into the groundwater of the region. $\mathrm{Na}-\mathrm{NO}_{3}(r=0.55)$ a good positive correlation suggests the human influence in enriching these ions into the groundwater. Anthropogenic sources such as leachate from dumping site and punctured sewer pipelines elucidate the significant correlation of $\mathrm{NO}_{3}-\mathrm{Cl}(r=0.60)$.

Enrichment of $\mathrm{NO}_{3}{ }^{-}$due to point and nonpoint sources in the vadose zone of aquifers because of its large ionic size and percolation of rainfall is generally leads to elevated concentration in water below the ground. Interpolation map of $\mathrm{NO}_{3}{ }^{-}$(Fig. 2) displays the most part of the region is affected with $\mathrm{NO}_{3}{ }^{-}$contamination, which exceeds the permissible limit of WHO (2004) except few patches in northwestern, southeastern and central part. But these patches with less concentration of nitrate are also at the verge of bypassing the allowed limit of nitrate, as set by WHO. The reasons behind high concentrations of nitrate in a fast urbanized part of Varanasi might be poor sewage, leaking of fecal matter from the septic tanks and locally unmanaged landfill sites, NOx generated from vehicular traffic movement and poultry farms (Patel et al. 2016). People are using various conventional decontamination technologies worldwide to protect themselves from the adverse effects of the elevated nitrate intake. Among the different nitrate removal methods available, the most frequently used are reverse osmosis, ion exchange, membrane technology, adsorption and biological treatments (Costa et al. 2018; Madhav et al. 2018).

\section{Hydrochemical Facies and Water type}

The word "Hydrochemical facies" describes the occurrence of groundwater modes in an aquifer system differing in their chemical compositions and is primarily a function of geology, the kinetics of the solution and aquifer flow patterns (Todd 1980). In a piper trilinear diagram, the water type was determined by plotting major ionic values (\% meq/l) of groundwater samples (Piper 1944) (Fig. 3). All groundwater samples point lies in the fields of $1,3,4,5$ and 9 as seen from the middle diamond-shaped plot of the chemical data

Table 3 Correlation matrix for the groundwater samples

\begin{tabular}{|c|c|c|c|c|c|c|c|c|c|c|c|c|}
\hline & $\mathrm{pH}$ & $\mathrm{EC}$ & TDS & $\mathrm{Ca}^{2+}$ & $\mathrm{Mg}^{2+}$ & $\mathrm{Na}^{+}$ & $\mathrm{K}^{+}$ & $\mathrm{HCO}_{3}^{-}$ & $\mathrm{SO}_{4}{ }^{2-}$ & $\mathrm{Cl}^{-}$ & $\mathrm{F}^{-}$ & $\mathrm{NO}_{3}^{-}$ \\
\hline $\mathrm{pH}$ & 1 & & & & & & & & & & & \\
\hline $\mathrm{EC}$ & -0.099 & 1 & & & & & & & & & & \\
\hline TDS & -0.109 & 0.920 & 1 & & & & & & & & & \\
\hline $\mathrm{Ca}^{2+}$ & 0.000 & -0.607 & -0.480 & 1 & & & & & & & & \\
\hline $\mathrm{Mg}^{2+}$ & -0.236 & 0.710 & 0.748 & -0.607 & 1 & & & & & & & \\
\hline $\mathrm{Na}^{+}$ & -0.308 & 0.844 & 0.822 & -0.232 & 0.542 & 1 & & & & & & \\
\hline $\mathrm{K}^{+}$ & 0.101 & 0.475 & 0.557 & -0.202 & 0.147 & 0.316 & 1 & & & & & \\
\hline $\mathrm{HCO}_{3}{ }^{-}$ & -0.063 & 0.534 & 0.587 & -0.154 & 0.552 & 0.579 & 0.430 & 1 & & & & \\
\hline $\mathrm{SO}_{4}{ }^{2-}$ & -0.404 & 0.518 & 0.571 & -0.203 & 0.413 & 0.585 & 0.120 & -0.163 & 1 & & & \\
\hline $\mathrm{Cl}^{-}$ & -0.291 & 0.775 & 0.855 & -0.211 & 0.609 & 0.827 & 0.543 & 0.474 & 0.675 & 1 & & \\
\hline $\mathrm{F}^{-}$ & -0.037 & 0.046 & 0.189 & -0.005 & 0.325 & 0.184 & 0.032 & 0.442 & 0.025 & 0.216 & 1 & \\
\hline $\mathrm{NO}_{3}^{-}$ & -0.205 & 0.593 & 0.650 & -0.098 & 0.566 & 0.547 & 0.301 & 0.603 & 0.116 & 0.600 & -0.137 & 1 \\
\hline
\end{tabular}


Fig. 2 Spatial distribution of nitrate in the study region

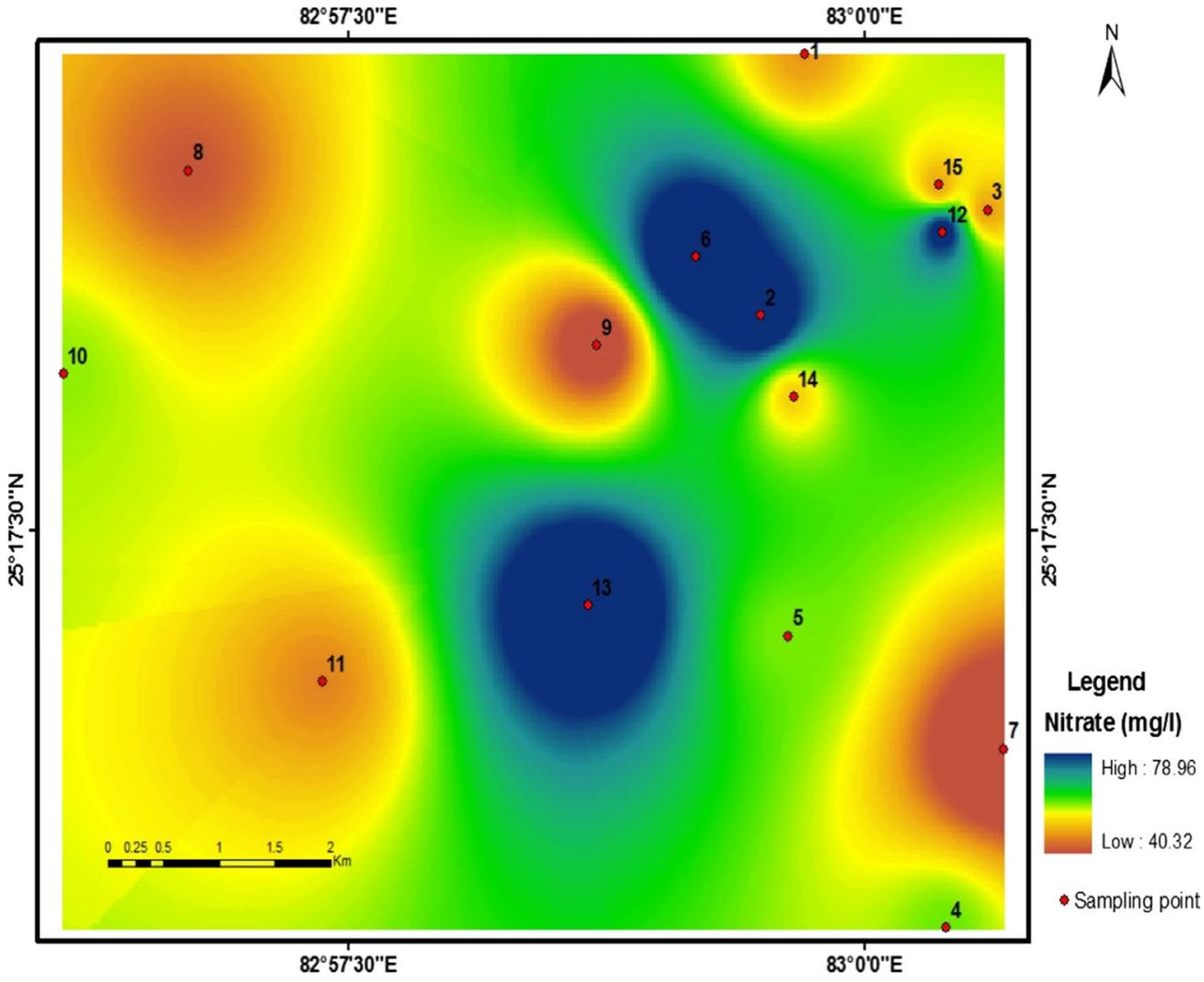

In the present study, all the samples fall in rock dominance for both ratios which means that the quality of groundwater is being affected by the chemical weathering of rock minerals (Fig. 4a, b).

\section{Water Quality Index}

Calculation of water quality index (WQI) is done to understand the quality of groundwater so as to know whether it is fit for drinking purposes.

The computed WQI values are divided into five classes: excellent $(<50)$, good $(50-100)$, poor $(100-200)$, very poor category (200-300) and unsuitable for drinking (>300) (Sahu and Sikdar 2008; Singh et al. 2016). The WQI value of the study region ranges from 16.09 to 53.03. Out of 15 samples, 93\% come under excellent water category and rest under good water category. The spatial allocation map of the WQI revealed that most of the area (Fig. 5) has excellent water. A patch of good water is in northeastern zone. In general, the study region has excellent to good water for drinking purpose.

\section{Classification of groundwater for irrigational purposes}

The excess amount of salts in the soil changes the structure of soil, its permeability and aeration which in turn link with the growth of plants (Mohan et al. 2000; Umar et al. 
Fig. 3 Piper trilinear diagram showing the relative cation and anion composition of groundwater samples
Table 4 Hydrochemical facies derived from piper diagram

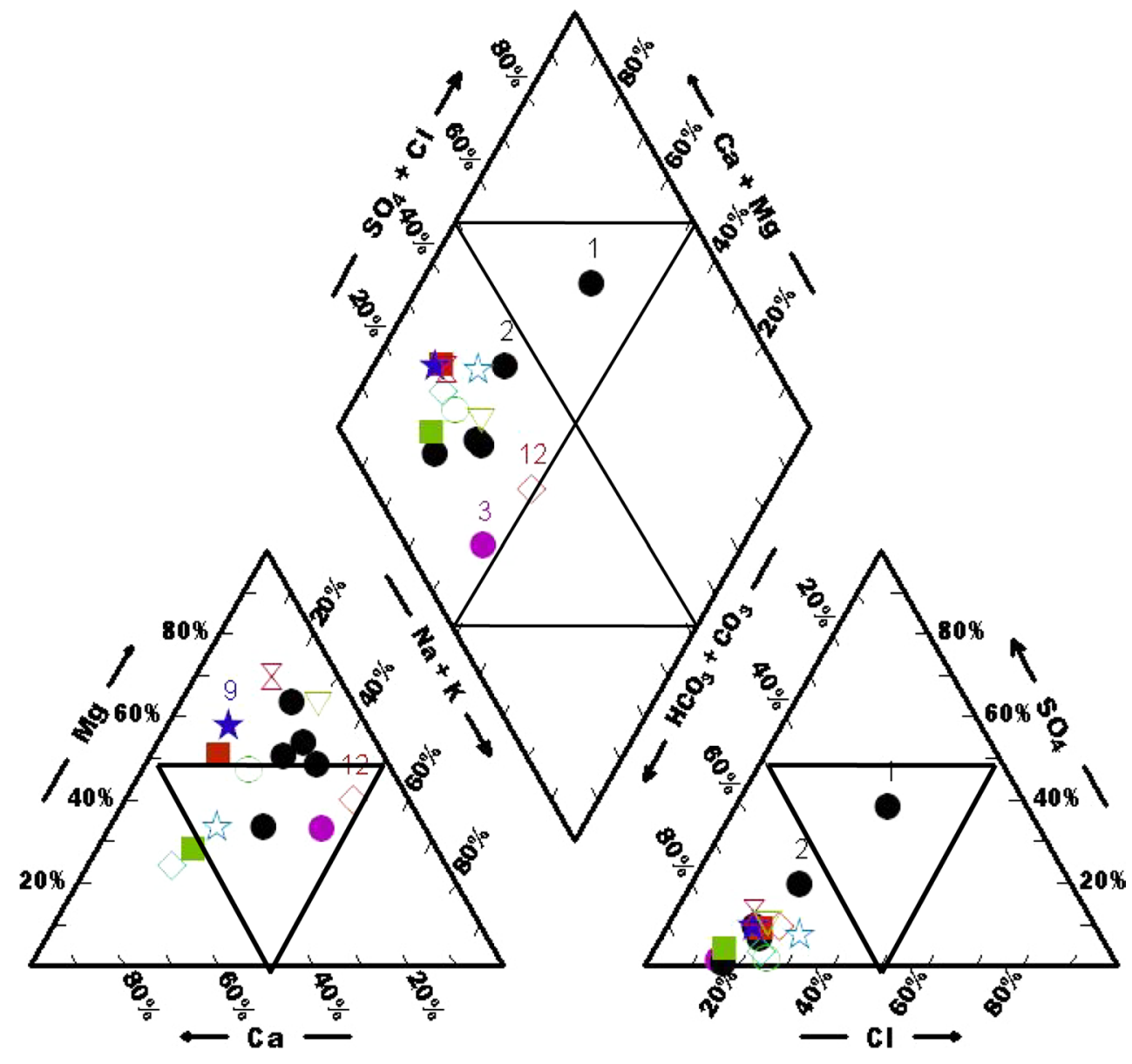

\begin{tabular}{lll}
\hline Subdivision & Characteristics of corresponding subdivision of diamond-shaped field & $\begin{array}{l}\text { Samples \% in } \\
\text { different fields }\end{array}$ \\
\hline 1 & Alkaline earths $(\mathrm{Ca}+\mathrm{Mg})$ exceed alkalies $(\mathrm{Na}+\mathrm{K})$ & 100 \\
2 & Alkalies exceed alkaline earths & 0 \\
3 & Weak acids $\left(\mathrm{CO} 3+\mathrm{HCO}_{3}\right)$ exceed strong acids $\left(\mathrm{SO}_{4}+\mathrm{Cl}+\mathrm{F}\right)$ & 93.33 \\
4 & Strong acids exceed weak acids & 6.66 \\
5 & Carbonate hardness(secondary alkalinity) exceeds 50\% & 93.33 \\
6 & Non-carbonate hardness (secondary salinity) exceeds 50\% & 0 \\
7 & Non-carbonate alkali (primary salinity) exceeds 50\% & 0 \\
8 & Carbonate alkali (primary alkalinity) exceeds 50\% & 0 \\
9 & None of the cation and anion pairs exceed 50\% & 6.66 \\
\hline
\end{tabular}

2001; Alam 2010, 2013). It does not allow water to reach different parts of the plants, which in turn reduces the agricultural productivity (Rao et al. 2013). So for long-term productivity, it is important to have knowledge of quality of water used for irrigation to understand what management changes are essential (Jalali 2011; Srinivasamoorthy et al. 2014).

The quality of irrigation water is decided by estimation of criteria like EC, salinity, percent sodium (\% Na), sodium adsorption ratio (SAR), RSC, permeability index (PI), Kelly's ratio and magnesium ratio.

\section{Residual sodium carbonate (RSC)}

Total $\mathrm{CO}_{3}{ }^{-}$and $\mathrm{HCO}_{3}{ }^{-}$affects the water quality as it causes the precipitation of alkaline earth chiefly $\mathrm{Ca}^{+2}$ and $\mathrm{Mg}^{+2}$, which in turn increases the percentage of $\mathrm{Na}^{+}$ (Eaton 1950). The $\mathrm{Na}^{+}$gets combined with the excess 
(a) 10000

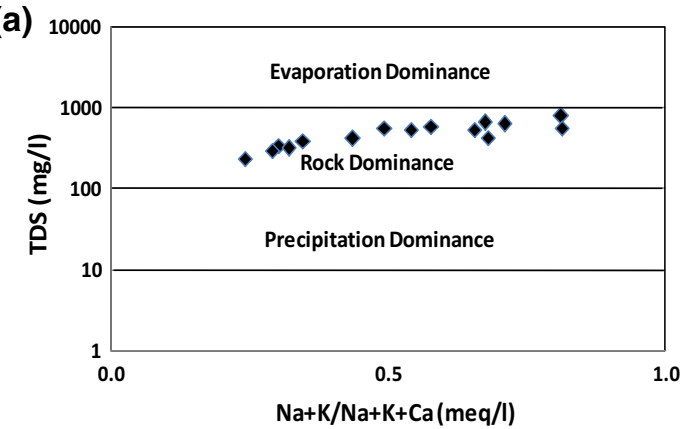

(b)

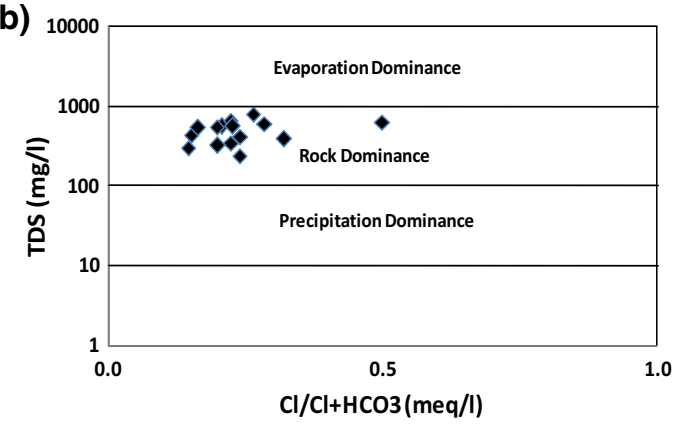

Fig. 4 Mechanism controlling groundwater chemistry (Gibbs 1970). a Gibbs ratio 1 (for cation), b Gibbs ratio 2 (for anion)

carbonates forming $\mathrm{NaHCO}_{3}$, called the residual sodium carbonate (RSC) (Rao et al. 2013). It affects the soil structure. The physical properties of soil are influenced by a large amount of sodium bicarbonate and carbonate, which is formed when the organic matter dissolves in the soil, leaving a black stain on its surface when it dries (Kumar et al. 2007; Srinivasamoorthy et al. 2014).

The RSC value in the study region ranged between -4.35 and 2.27 (Table 5). Classification of groundwater sample of the study area can be done based on RSC value as suitable or safe, if the RSC is less than $1.25 \mathrm{meq} / \mathrm{l}$; marginally suitable, if the RSC is between 1.25 and $2.50 \mathrm{meq} / \mathrm{l}$; and unsuitable if the RSC is more than $2.50 \mathrm{meq} / 1.87 \%$ of samples fall in a good category, $13 \%$ fall in the medium category, which clearly show that nearly all groundwater samples are fit for irrigation.

\section{Percent sodium and EC}

Sodium ion is of great significance for the categorization of irrigation water as it reacts with the soil and reduces its permeability. Therefore, assessment of water fitness for irrigation purposes is widely done on the percentage of $\mathrm{Na}^{+}$ (Wilcox 1955). Na \% decreases the permeability of soil and results in poor internal drainage of soil (Subramani et al. 2005; Singaraja et al. 2014).

$\mathrm{Na} \%$ in the study region ranges between 13.50 and 48.86 (Table 5). In the current study, all samples are under $60 \%$, which are classified as excellent by permissible category for irrigational purposes. The chemical quality of groundwater samples was analyzed by plotting analytical data (Wilcox 1948) relating EC and Na \% (Fig. 6). It is observed that $47 \%$ of the samples come under excellent to good class and $53 \%$ of the samples come under good to permissible class (Table 6). Clays tend to absorb high concentrations of $\mathrm{Na}$
Fig. 5 Spatial distribution of water quality index in the study region

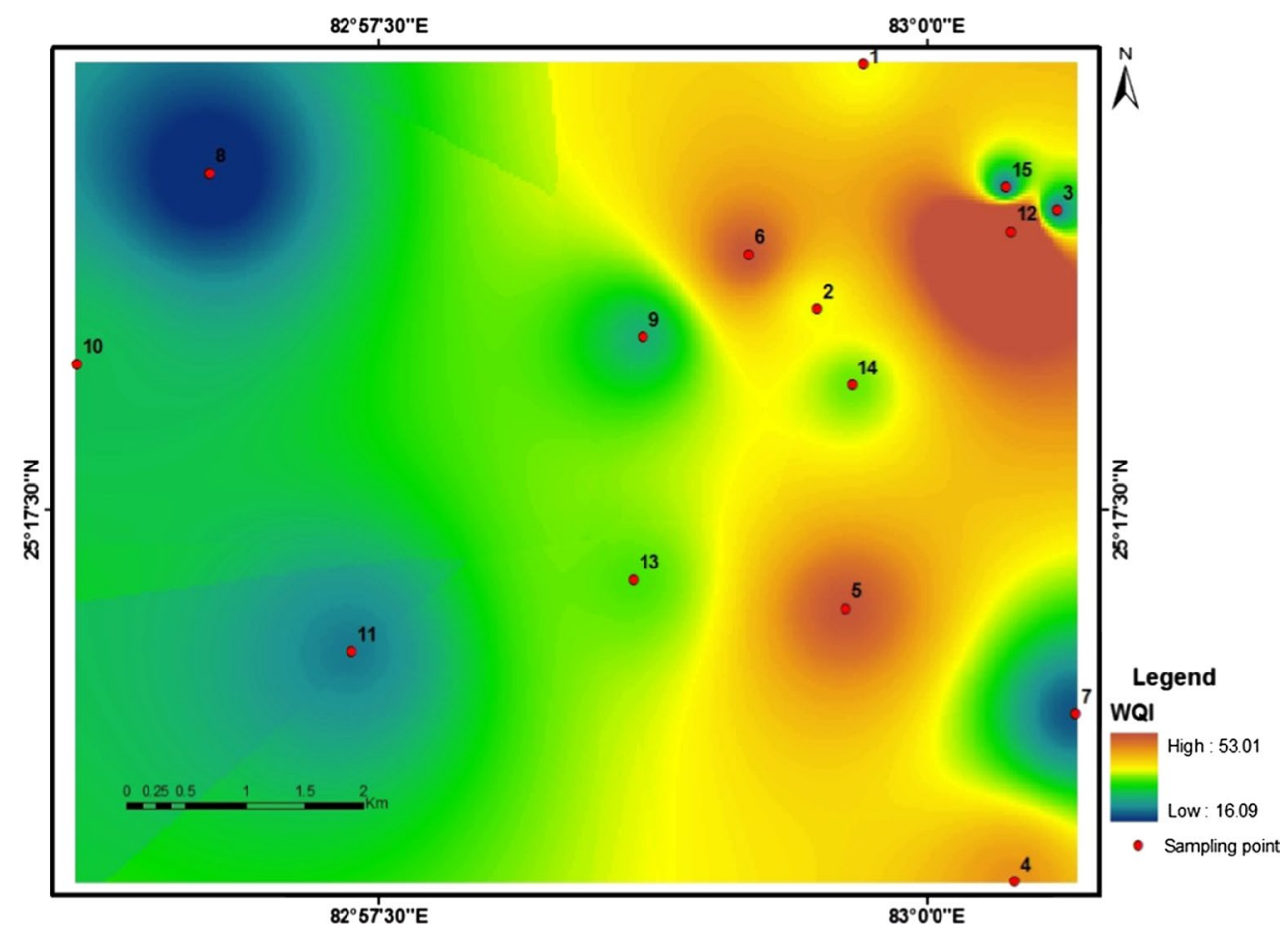


Table 5 Categorization of groundwater samples for irrigational purposes

\begin{tabular}{|c|c|c|c|c|}
\hline Quality parameter & $\begin{array}{l}\text { Sample range } \\
\text { (Min-Max.) }\end{array}$ & Range & Classification & Sample No. $(\%)$ \\
\hline \multirow[t]{5}{*}{$\mathrm{Na} \%(\mathrm{meq} / \mathrm{l})$} & & $0-20$ & Excellent & 27 \\
\hline & & $20-40$ & Good & 60 \\
\hline & $13.50-48.86$ & $40-60$ & Permissible & 13 \\
\hline & & $60-80$ & Doubtful & - \\
\hline & & $>80$ & Unsuitable & - \\
\hline \multirow[t]{4}{*}{ SAR (meq/l) } & & $0-10$ & $\begin{array}{l}\text { Excellent (appropriate for all type of crops and soil except for those } \\
\text { crops sensitive to } \mathrm{Na} \text { ) }\end{array}$ & 100 \\
\hline & $0.53-2.37$ & $10-18$ & Good (suitable for coarse textured or organic soil with permeability) & - \\
\hline & & $18-26$ & Fair (harmful for almost all soil) & - \\
\hline & & $>26$ & Poor (unsuitable for irrigation) & - \\
\hline \multirow[t]{3}{*}{$\mathrm{RSC}(\mathrm{meq} / \mathrm{l})$} & & $<1.25$ & Good & 87 \\
\hline & -4.35 to 2.27 & $1.25-2.5$ & Medium & 13 \\
\hline & & $>2.5$ & Bad & - \\
\hline \multirow[t]{4}{*}{$\mathrm{EC}(\mu \mathrm{S} / \mathrm{cm})$} & & $<250$ & Low salinity hazards (good) & - \\
\hline & $430-1110$ & $250-750$ & Medium salinity hazard (moderate) & 47 \\
\hline & & $750-2250$ & High salinity hazard (poor) & 53 \\
\hline & & $>2250$ & Very high salinity hazard (very poor) & - \\
\hline \multirow[t]{3}{*}{ Kelly's ratio (meq/l) } & & $<1$ & Suitable & 100 \\
\hline & $0.15-0.81$ & $1-2$ & Marginally suitable & - \\
\hline & & $>2$ & Unsuitable & - \\
\hline \multirow[t]{2}{*}{ Mg hazards (meq/l) } & $29.58-90.5$ & $<50$ & Suitable for irrigation & 27 \\
\hline & & $>50$ & Harmful for irrigation & 73 \\
\hline \multirow[t]{3}{*}{ PI (meq/l) } & & Class 1 & Max. permeability & 93 \\
\hline & $38.85-77.58$ & Class 2 & $75 \%$ of max. permeability & 7 \\
\hline & & Class 3 & $25 \%$ of max. permeability & - \\
\hline
\end{tabular}

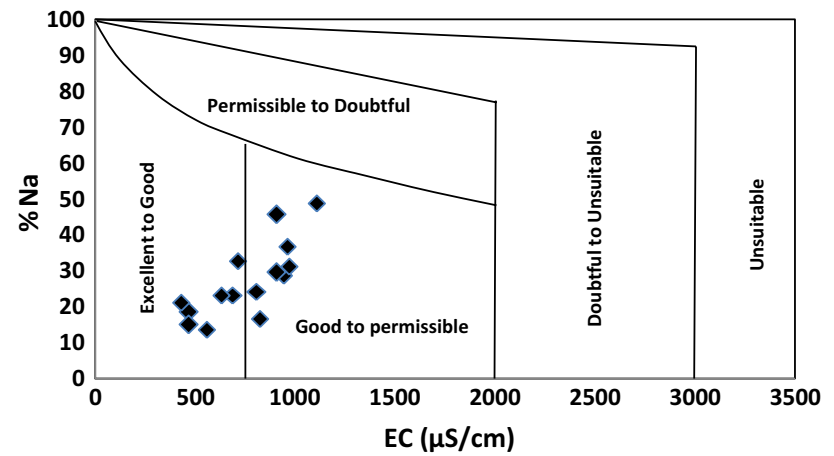

Fig. 6 Rating of groundwater samples based on electrical conductivity and percent sodium (Wilcox 1948)

${ }^{+}$in irrigation water and to displace $\mathrm{Ca}^{2+}$ and $\mathrm{Mg}^{2+}$ by ion exchange, lowering the permeability and thus making the soil poor in drainage (Raju et al. 2009; Rao et al. 2013; Ahamed et al. 2013; Xiao et al. 2014).
Table 6 Categorization of groundwater based on Wilcox diagram (Wilcox 1948)

\begin{tabular}{lll}
\hline Category & No. of samples & $\%$ sample \\
\hline Excellent to good & 7 & 47 \\
Good to permissible & 8 & 53 \\
Permissible to doubtful & - & - \\
Doubtful to unsuitable & - & - \\
Unsuitable & - & - \\
\hline
\end{tabular}

\section{Salinity hazard versus alkali hazard}

To evaluate quality of water that whether it is suitable for irrigation, the hazards, which are linked with the salinity and $\mathrm{Na}^{+}$, play a vital part in the development of plant growth. High salt content (high EC) in water makes the soils saline (Raju 2007; Raju et al. 2009), which is the foremost reason for crop loss. $\mathrm{Na}^{+}$forms alkaline soils, with a combination of carbonates and saline soils, with a coalition of $\mathrm{Cl}^{-}$, which reduces the growth of plants (Rao et al. 2013). Salinity arises in groundwater when the rocks get weathered, input of salts 
from anthropogenic sources and leaching from top soil along with small influence on climate (Singaraja et al. 2014).

The measured value of EC is varied between 430 and $1110 \mu \mathrm{S} / \mathrm{cm}$ (Table 5) Irrigation water was qualified by Richards (1954) into four categories on the basis of EC values. The zones ( $\mathrm{C} 1-\mathrm{C} 4)$ have the value of $\mathrm{EC}<250$ (low), 250-750 (medium), 750-2250 $\mu \mathrm{S} / \mathrm{cm}$ (high) and more than $2250 \mu \mathrm{S} / \mathrm{cm}$ (Very high), respectively. As per Richards, it is observed that $47 \%$ of the samples fall in moderately saline, $53 \%$ of the samples in the highly saline zone (Table 5).

In the present study, SAR value ranges between 0.53 and 2.37 (Table 5). In terms of categorization of irrigation water, sodium hazard is conveyed, as low ( $\mathrm{S} 1:<10)$, medium ( $\mathrm{S} 2$ : 10-18), high (S3: 18-26) and very high (S4:>26). In this study, all samples (100\%) fall in (low) excellent category.

\section{USSL 1954}

US Salinity Laboratory Staff (USSL 1954) diagrams were used to classify the samples. The USSLS diagram links sodium adsorption ratio (SAR), which conveys the sodium or alkali hazard, to EC (salinity hazard) (Fig. 7). $47 \%$ of the groundwater samples fall in the zone of $\mathrm{C} 2 \mathrm{~S} 1$ (medium salty and low sodium), which is suited for all plants but drainage should be good. $53 \%$ of samples fall under the zone C3S1 (high salty and low sodium), which can be used with little danger of exchangeable sodium for irrigation of the majority of the soils and crops (Raju et al. 2009, 2011).

\section{Permeability index}

Based on PI (Doneen1964), a standard has been developed for estimating the fitness of water for irrigation uses. On the basis of PI, the water quality can be classified into

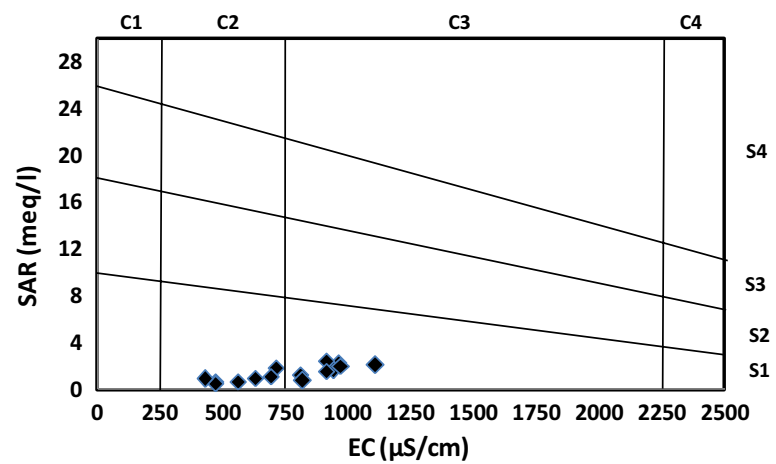

$$
\begin{aligned}
& \text { Sodium Hazard } \\
& \text { S1: Low } \\
& \text { S2: Medium } \\
& \text { S3: High } \\
& \text { S4: Very high }
\end{aligned}
$$

$$
\begin{aligned}
& \text { Salinity Hazard } \\
& \text { C1: Low } \\
& \text { C2: Medium } \\
& \text { C3: High } \\
& \text { C4: Very high }
\end{aligned}
$$

Fig. 7 Rating of groundwater samples in relation to salinity hazard and alkali hazard (after US Salinity Laboratory diagram 1954) three classes. The class I is suitable for irrigation, which has $100 \%$ maximum permeability. The class II is marginally fit for irrigation, which shows $75 \%$ maximum permeability. The class III is unsuitable for irrigation, which is linked with the $25 \%$ maximum permeability. In the present study, PI ranges from 38.85 to 77.58 (Table 5). Based on PI values, 93\% of samples come under class I category and 7\% under class II category in Doneen's chart (Fig. 8). In general, nearly all the samples lie in class I group signifying water is good for irrigation uses (Arumugam and Elangovan 2009; Srinivasamoorthy et al. 2014).

\section{Kelly's ratio}

Kelly's ratio is utilized to examine the fitness of groundwater for agricultural uses. $\mathrm{Na}^{+}$measured against $\mathrm{Ca}^{2+}$ and $\mathrm{Mg}^{2+}$ was developed by Kelly (1963). The groundwater having a Kelly's ratio $>1$ is not considered fit for irrigation (Sundaray et al. 2009; Srinivasamoorthy et al. 2014; Patel et al. 2016). Kelly's ratio ranges between 0.15 and 0.81 (Table 5), which was found $<1$ and seems suitable for irrigation purposes.

\section{Magnesium Hazard (MH)}

Szaboles in 1964 has given MH ratio for checking the fitness of water for irrigation. In general, $\mathrm{Ca}^{2+}$ and $\mathrm{Mg}^{2+}$ are in a state of equilibrium in nearly all waters, but the salinity of water will add to with rising amount of magnesium in water, which in turns affects the crop yield (Joshi et al. 2009; Singaraja et al. 2014). Water having MH value $>50$ is believed to be unsafe and thus is considered not appropriate for irrigation because it declines the crop yield (Sreedevi 2004; Rao et al. 2013; Singaraja et al. 2014). The value of MH ranges between 29.58 and 90.5 . $73 \%$ of samples (Table 5) fall $>50$ of $\mathrm{MH}$ value, which are not

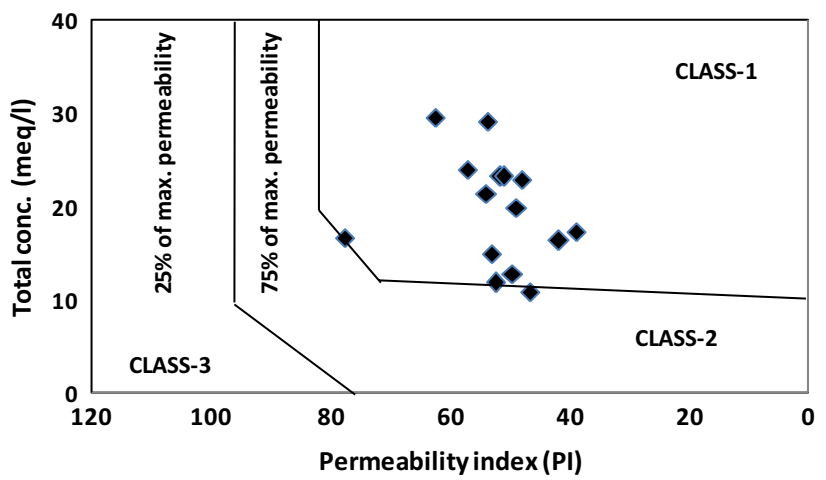

Fig. 8 Groundwater suitability for irrigation based on Doneen permeability index plot (1964) 
suitable for irrigation, while the remaining $27 \%$ samples found below 50, making it suitable for irrigation.

\section{Conclusion}

The subsurface water of this study is faintly alkaline by nature. Hydrogeochemistry of the Varanasi area shows that most of the samples for majority of parameters lie in the acceptable limits set by WHO (2004) standard, except nitrate. $80 \%$ of the groundwater samples were found to have nitrate concentrations beyond the limit prescribed by WHO, i.e., $50 \mathrm{mg} / \mathrm{l}$. The high concentration of nitrate may be due to poor sewerage, human excreta leakage from septic tanks, locally mismanaged disposal of solid waste, agricultural activities, wastewater irrigation and irrigation runoff. For safe drinking water, ion exchange, reverse osmosis and distillation are the useful methods of nitrate remotion. $\mathrm{Ca}-\mathrm{Mg}-\mathrm{HCO}_{3}$ was inferred as major hydrogeochemical facies from Piper trilinear diagram. Hydrogeochemistry tells about the order of cation and anion abundance which is $\mathrm{Na}^{+}>\mathrm{Mg}^{2+}>\mathrm{Ca}^{2+}>\mathrm{K}^{+}$and $\mathrm{HCO}_{3}{ }^{-}>\mathrm{Cl}^{-}>\mathrm{NO}_{3}{ }^{-}>\mathrm{SO}_{4}{ }^{2-}>\mathrm{F}^{-}$, respectively. Correlation matrix is used to identify the sources of major ions in subsurface water. TDS is positively correlated with $\mathrm{Mg}^{2+}$ $(r=0.75), \mathrm{Na}^{+}(r=0.82), \mathrm{K}^{+}(r=0.56), \mathrm{HCO}_{3}{ }^{-}(r=0.59)$, $\mathrm{SO}_{4}{ }^{2-}(r=0.57)$. Very good correlation of $\mathrm{NO}_{3}-\mathrm{Cl}$ $(r=0.60)$ and $\mathrm{Na}-\mathrm{NO}_{3}(r=0.55)$ signifies the anthropogenic input along with geogenic contribution providing these ions into groundwater of this study. Gibb's value indicates chemical weathering of rock minerals is affecting the groundwater quality. The WQI value of the study region ranges from 16.09 to 53.03. Almost $93 \%$ samples come under excellent water category and rest $7 \%$ under good water category. Overall, the study region shows excellent to good water for drinking purpose. As per the categorization of water for irrigation purpose by using various indices, water is fit for agricultural uses.

Open Access This article is distributed under the terms of the Creative Commons Attribution 4.0 International License (http://creativeco mmons.org/licenses/by/4.0/), which permits unrestricted use, distribution, and reproduction in any medium, provided you give appropriate credit to the original author(s) and the source, provide a link to the Creative Commons license, and indicate if changes were made.

\section{References}

Abdesselam S, Halitim A, Jan A, Trolard F, Bourrie G (2013) Anthropogenic contamination of groundwater with nitrate in arid region: case study of southern Hodna (Algeria). Environ Earth Sci 70:2129-2141
Ahamed AJ, Loganathan K (2017) Water quality concern in the Amaravathi River Basin of Karur district: a view at heavy metal concentration and their interrelationships using geostatistical and multivariate analysis. Geol Ecol Landsc 1(1):19-36

Ahamed AJ, Loganathan K, Ananthakrishnan S, Manikandan K (2013) Assessment of groundwater quality for irrigation use in Alathur Block, Perambalur District, Tamilnadu, South India. Appl Water Sci 3:763-771. https://doi.org/10.1007/s13201-013-0124-z

Ako AA, Eyong GET, Shimada J, Koike K, Hosono T, Ichiyanagi K, Richard A, Tandia BK, Nkeng GE, Roger NN (2014) Nitrate contamination of groundwater in two areas of the Cameroon Volcanic Line (Banana Plain and Mount Cameroon area). Appl Water Sci 4:99-113

Alam F (2010) Aquifer system and groundwater resource evaluation in parts of Hindon-Yamuna watershed in parts of western Uttar Pradesh, Unpublished Ph.D. thesis, Aligarh Muslim University, Aligarh

Alam F (2013) Evaluation of hydrogeochemical parameters of groundwater for suitability of domestic and irrigational purposes: a case study from central Ganga Plain, India. Arab J Geosci 7(10):4121-4131. https://doi.org/10.1007/s1251 7-013-1055-6

Alaya MB, Saidi S, Zemni T, Zargouni F (2014) Suitability assessment of deep groundwater for drinking and irrigation use in the Djeffara aquifers (Northern Gabes, south-eastern Tunisia). Environ Earth Sci 71(8):3387-3421

Alexander AC, Ndambuki J, Salim R, Manda A (2017) Assessment of spatial variation of groundwater quality in a mining basin. Sustainability 9(5):823

Amalraj A, Pius A (2018) Assessment of groundwater quality for drinking and agricultural purposes of a few selected areas in Tamil Nadu South India: a GIS-based study. Sustain Water Res Manag 4(1):1-21

Annapoorna H, Janardhana MR (2015) Assessment of groundwater quality for drinking purpose in rural areas surrounding a defunct copper mine. Aquat Proc 4:685-692

APHA (2005) Standard methods for the examination of water and wastewater, 20th edn. Washington

Appelo CAJ, Postma D (1993) Groundwater, geochemistry and pollution. A A Balkema, Rotterdam

Arumugam K, Elangovan K (2009) Hydrochemical characteristics and groundwater quality assessment in Tirupur Region, Coimbatore District, Tamil Nadu, India. Environ Geol 58:1509-1520. https:// doi.org/10.1007/s00254-008-1652-y

Costa DD, Gomes AA, Fernandes M, da Costa Bortoluzzi R L, Magalhaes MDLB, Skoronski E (2018) Using natural biomass microorganisms for drinking water denitrification. J Environ Manage 217:520-530

Davis SN, De Wiest RJM (1966) Hydrogeology, vol 463. Wiley, New York

Doneen LD (1964) Notes on water quality in agriculture, published as a water science and engineering paper 4001. Department of water sciences and engineering, University of California, Berkeley

Eaton FM (1950) Significance of carbonate in irrigation waters. Soil Sci 69(2):123-133

Ehya F, Mosleh A (2018) Hydrochemistry and quality assessment of groundwater in Basht Plain, Kohgiluyeh-va-Boyer Ahmad Province, SW Iran. Environ Earth Sci 77(5):164

Gibbs RJ (1970) Mechanism controlling world's water chemistry. Science 170:1088-1090

Gillardet J, Dupre B, Louvat P, Allegre CJ (1999) Global silicate weathering and $\mathrm{CO}_{2}$ consumption rates deduced from the chemistry of large rivers. Chem Geol 159:3-10

Gowd SS (2005) Assessment of groundwater quality for drinking and irrigation purposes: a case study of Peddavanka watershed, Anantapur District, Andhra Pradesh. India. Environ Geol 48(6):702-712 
Han G, Liu CQ (2004) Water geochemistry controlled by carbonate dissolution: a study of the river waters draining Karst-dominated terrain, Guizhou province. China. Chem Geol 204(1):21

Jalali M (2009) Geochemistry characterization of groundwater in an agricultural area of Razan, Hamadan. Iran. Environ Geol $56: 1479-1488$

Jalali M (2011) Hydrogeochemistry of groundwater and its suitability for drinking and agricultural use in Nahavand, Western Iran. Nat Resour Res 20(1):65-73

Jamshidzadeh Z, Barzi MT (2018) Groundwater quality assessment using the potability water quality index (PWQI): a case in the Kashan plain, Central Iran. Environ Earth Sci 77(3):59

Joshi DM, Kumar A, Agrawal N (2009) Assessment of the irrigation water quality of river Ganga in Haridwar District India. J of chem 2(2):285-292

Kelly WP (1963) Use of saline irrigation water. Soil Sci 95(4):355-391

Kumar M, Kumari K, Ramanathan AL, Saxena R (2007) A comparative evaluation of groundwater suitability for irrigation and drinking purposes in two intensively cultivated districts of Punjab, India. Environ Geol 53:553-574. https://doi.org/10.1007/s0025 4-007-0672-3

Li P, Wu J, Qian H (2013) Assessment of groundwater quality for irrigation purposes and identification of hydrogeochemical evolution mechanisms in Pengyang County, China. Environ Earth Sci 69:2211-2225

Madhav S, Ahamad A, Kumar A, Kushawaha J, Singh P, Mishra PK (2018) Geochemical assessment of groundwater quality for its suitability for drinking and irrigation purpose in rural areas of Sant Ravidas Nagar (Bhadohi), Uttar Pradesh. Geol Ecol Landsc 1-10

Mahmoudi N, Nakhaei M, Porhemmat J (2017) Assessment of hydrogeochemistry and contamination of Varamin deep aquifer, Tehran Province, Iran. Environ Earth Sci 76:370

Mason CF (2002) Biology of freshwater pollution. Pearson Education, New York City

Mohan R, Singh AK, Tripathi JK, Choudhary GC (2000) Hydrochemistry and quality assessment of groundwater in Naini industrial area, Allahabad District, Uttar Pradesh. J GeolSoc India 55:77-89

Patel P, Raju NJ, Reddy BSR, Suresh U, Gossel W, Wycisk P (2016) Geochemical processes and multivariate statistical analysis for the assessment of groundwater quality in the Swarnamukhi River basin, Andhra Pradesh, India. Environ Earth Sci 75(7):1-24

Piper AM (1944) A graphic procedure in the geochemical interpretation of water-analyses. Trans Am Geophys Union 25:914-923

Prasanth SS, Magesh NS, Jitheshlal KV, Chandrasekar N, Gangadhar K (2012) Evaluation of groundwater quality and its suitability for drinking and agricultural use in the coastal stretch of Alappuzha District, Kerala, India. Appl Water Sci 2(3):165-175

Raju NJ (2007) Hydrogeochemical parameters for assessment of groundwater quality in the upper Gunjanaeru River basin, Cuddapah District, Andhra Pradesh, South India. Environ Geol 52:1067-1074. https://doi.org/10.1007/s00254-006-0546-0

Raju NJ (2012) Evaluation of hydrogeochemical processes in the Pleistocene aquifers of Middle Ganga Plain, Uttar Pradesh, India. Environ Earth Sci 65:1291-1308

Raju NJ, Ram P, Dey S (2009) Groundwater quality in the lower Varuna river basin, Varanasi district, Uttar Pradesh. J Geol Soc India 73(2): 178

Raju NJ, Shukla UK, Ram P (2011) Hydrogeochemistry for the assessment of groundwater quality in Varanasi: a fast-urbanizing center in Uttar Pradesh, India. Environ Monit Assess 173(1-4):279-300

Raju NJ, Ram P, Gossel W (2014) Evaluation of groundwater vulnerability in the lower Varuna catchment area, Uttar Pradesh, India using AVI concept. J Geol Soc India 83(3):273-278

Raju NJ, Patel P, Gurung D, Ram P, Gossel W, Wycisk P (2015) Geochemical assessment of groundwater quality in the Dun valley of central Nepal using chemometric method and geochemical modeling. Groundw Sustain Dev 1(1):135-145

Raju NJ, Patel P, Reddy BSR, Suresh U, Reddy TVK (2016) Identifying source and evaluation of hydrogeochemical processes in the hard rock aquifer system: geostatistical analysis and geochemical modeling techniques. Environ Earth Sci 75(16):1157

Rao GT, Rao VG, Rao YS, Ramesh G (2013) Study of hydrogeochemical processes of the groundwater in Ghatprabha river sub-basin, Bagalkot District, Karnataka, India. Arab J Geosci 6(7):2447-2459

Richards LA (1954) Diagnosis and improvement of saline soil, agiculture, 160, Handbook 60, US Department of agriculture, Washington DC

Sahu P, Sikdar PK (2008) Hydrochemical framework of the aquifer in and around East Kolkata wetlands, West Bengal, India. Environ Geol 55:823-835

Sener S, Sener E, Davraz A (2017) Evaluation of water quality using water quality index (WQI) method and GIS in Aksu River (SWTurkey). Sci Total Environ 584:131-144

Shukla UK, Raju NJ (2008) Migration of the Ganga River and its implication on hydro-geological potential of Varanasi area, UP. India. J Earth Syst Sci 117(4):489-498

Singaraja C, Thivya C, Chidambaram S, Thilagavathi R, Anandhan P, Sarathidasan J, Prasanna MV (2014) Determination of the utility of groundwater with respect to the geochemical parameters: a case study from Tuticorin District of Tamil Nadu (India). Environ Dev Sustain 16:689-721. https://doi.org/10.1007/s10668-013-9502-9

Singh AK, Tewary BK, Sinha A (2011) Hydrochemistry and quality assessment of groundwater in part of NOIDA metropolitan city, Uttar Pradesh. J Geol Soc India 78(6):523-540

Singh S, Raju NJ, Gossel W, Wycisk P (2016) Assessment of pollution potential of leachate from the municipal solid waste disposal site and its impact on groundwater quality, Varanasi environs, India. Arab J Geosci 9(2):1-12

Sreedevi PD (2004) Groundwater quality of Pageru river basin, Cudapah district, Andhra Pradesh. J Geol Soc India 64:619-636

Srinivasamoorthy K, Gopinath M, Chidambaram S, Vasanthavigar M, Sarma VS (2014) Hydrochemical characterization and quality appraisal of groundwater from Pungar sub basin, Tamilnadu, India. J King Saud Univ-Science 26:37-52

Stadler S, Talma AS, Tredoux G, Wrabel J (2012) Identification of sources and infiltration regimes of nitrate in the semi-arid Kalahari: regional differences and implications for groundwater management. Water SA 38(2):213-224

Subramani T, Elango L, Damodarasamy SR (2005) Groundwater quality and its suitability for drinking and agricultural use in Chithar River Basin, Tamilnadu, India. Environ Geol 47:1099-1110

Sundaray SK, Nayak BB, Bhatta D (2009) Environmental studies on river water quality with reference to suitability for agricultural purposes: Mahanadi river estuarine system, India-a case study. Environ Monit Assess 155:227-243

Suthar S, Bishnoi P, Singh S, Mutiyar PK, Nema AK, Patil NS (2009) Nitrate contamination in groundwater of some rural areas of Rajasthan, India. J Hazard Mater 171:189-199

Szaboles I, Darab C (1964) The influence of irrigation water of high sodium carbonate content of soils. In: Proceedings of 8th international congress of ISSS, Trans, II, pp 803-812

Todd DK (1980) Groundwater hydrology, 2nd edn. Wiley, New York, p 535

Umar A, Umar R, Ahmad MS (2001) Hydrogeological and hydrochemical framework of regional aquifer system in Kali-Ganga sub-basin, India. Environ Geol 40:602-611

Umar R, Ahmed I, Alam F, Khan MM (2009) Hydrochemical characteristics and seasonal variations in groundwater quality of an alluvial aquifer in parts of Central Ganga Plain, Western Uttar Pradesh, India. Environ geol 58(6):1295-1300 
US Salinity Laboratory (1954) Diagnosis and improvement of saline and alkaline soils,Agricultural handbook No. 60. USDA, pp 160

Varol S, Davraz A (2014) Assessment of geochemistry and hydrogeochemical processes in groundwater of the Tefenni plain (Burdur/ Turkey). Environ Earth Sci 71:4657-4673

Wilcox LV (1948) The quality of water for irrigation use, vol 40, US Department of agriculture Technology Bulletin 962, Washington DC

Wilcox LV (1955) Classification and use of irrigation waters (p 19). U.S. Department of Agriculture, Circulation 969, Washington, DC

World Health Organization (2004) Guideline for drinking water quality, 4th edn. WHO, Geneva, p 340
Xiao J, Zhangdong J, Jin W (2014) Assessment of the Hydrogeochemistry and Groundwater Quality of the Tarim River Basin in an Extreme Arid Region, NW China. Environ Manag 53:135-146. https://doi.org/10.1007/s00267-013-0198-2

Publisher's Note Springer Nature remains neutral with regard to jurisdictional claims in published maps and institutional affiliations. 